\title{
Editorial
}

\section{The road to global financial standards: The missing fourth pillar?}

The Enron Debacle in the USA and the shock waves now rippling throughout the rest of the global village highlight the possibility of problems in accountancy standards and for failures to arise in the application of audit practices in the most developed systems. This and other allegations of auditing failures have stimulated the debate on the need for international auditing standards to be developed. Indeed, while the debate seems set to continue with vigour in the coming months, there would appear to be a growing international consensus on the need for change to accounting standards. The debate has been increasingly prominent in the world of prudential supervision.

The latter part of the twentieth century saw the rapid development of a global financial marketplace in a great leap forward, spurred both by rapid technological change and the renewed dominance of free-market principles. The beginning of the new century is likely to witness the blooming of a hundred flowers in the sense that there will be the development of myriad financial products and sophisticated financial instruments by financial institutions. Increasingly, those outside the loop will find financial businesses difficult to comprehend, and 'snapshot' financial reporting will become less valuable.

In this brave new financial world, prudential supervisors, international accountancy bodies, financial institutions, investors and depositors seem set to continue the debate on the desirability and fea- sibility of the introduction of global financial reporting standards with renewed impetus.

At the heart of the debate is the desire for globally accepted standards for financial reporting that will ensure that essential information about institutions' financial situations, performance and risk profiles reaches the public arena, providing another tool in protecting the global financial architecture from the increased frequency of instability that to date has become one of the hallmarks of the global market-led financial system as seen in the crises in East Asia, Latin America and Japan.

January saw the timely publication by the Basel Committee on Banking Supervision and the International Auditing Practices Committee of an updated paper on the relationship between banking supervisors and a bank's external auditors. The paper seeks to provide information and guidance on how the relationship between bank auditors and supervisors can be strengthened to their mutual advantage, taking into account the Basel Committee's core principles for effective banking supervision. The paper describes the primary responsibilities of the board of directors and management, examines the essential features of the role of the external auditor, examines the essential features of the role of supervisors, reviews the relationship between bank supervisors and the external auditor and describes additional ways in which auditors and the auditing profession can contribute to the supervisory process. 
Addressing the US-Europe Symposium in Switzerland at the end of February, Andrew Crockett, General Manager of the Bank for International Settlements and Chairman of the Financial Stability Forum, talked of global financial reporting standards as a critical pillar in the international financial architecture and provided a threepoint definition of financial reporting as referring to 'three sets of arrangements: arrangements for the measurement of the financial position, performance and risks of firms; arrangements for their presentation and disclosure; and the correspondent monitoring and enforcement mechanisms'. Crocket painted a grim picture in which the failure of accountancy standards and the consequent lack of transparency not only contributed to the Asian crisis, but also to the voracity of that crisis. No doubt, progress towards new global financial reporting standards is being made, but as the debate rumbles on, for the time being at least perhaps the last salient word should go to Crocket who warned delegates that 'In today's highly integrated world, a set of global financial reporting standards that is accepted and, equally importantly, widely and effectively implemented is a critical missing pillar in the emerging financial architecture.'

Paul Clement

IALS Editor

March 2002 